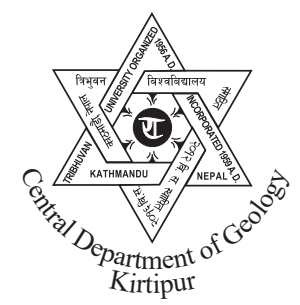

\title{
Fluvial morphology and dynamics of the Godavari Khola, southeast Kathmandu, Central Nepal
}

\author{
*Swarup Singh Karki and Naresh Kazi Tamrakar \\ Central Department of Geology, Tribhuvan University, Kathmandu, Nepal
}

\begin{abstract}
The Godavari Khola flowing from the south to the north contributes the Hanumante Khola, which is one of important tributaries of the Bagmati River, flowing from the eastern part of the Kathmandu Basin. Recently, the Godavari Khola has been suffering from human encroachments due to rapid urbanization. Studying nature and dynamics of the stream are important works if the stream has to be made less affected and well managed. The present study aims to establish fluvial morphology and stability status of the Godavari Khola. For these purposes, the watershed was analysed for morphometric parameters and planform fluvial morphology, and thirteen representative segments were surveyed from upstream to downstream of the Godavari Khola for recording and analysing sediment properties, stream cross-sections and profiles, and hydraulic parameters, river dynamics and stability.

The Godavari River is a fifth order stream, the two upstream segments of which are bedrock channels, and the rest of the segments are alluvial channels. The segments are classified into six kinds such as C4-, C5-, B3-, B4-, E4- and F4-type streams. The upstream segments are of B4-, B3- and 'F4'-types which show entrenched, steep, gravel to cobble grade streams. The downstream segments are of C4-, C5-, E4- and F4-types showing non-entrenched to low entrenched streams with gentle slopes, high sinuosity and gravel to sand grade bed materials. The stability status of the Godavari Khola shows that the stream segments 1, 2, 11 and 13 lie in the degrading condition whereas the remaining nine segments lie in the aggrading condition. Because of the huge width/depth ratio in majority of the downstream channels, bank erosion is relatively prone in the downstream segments of the Godavari Khola, whereas bed incision is prone in segments 11 and 13.
\end{abstract}

Key words: Fluvial morphology, stream classification, aggrading stream, degrading stream, Bagmati River

Received: 4 June, 2016

Accepted: 1 July, 2016

\section{INTRODUCTION}

The Godavari Khola is one of the major tributaries of the Hanumante Khola, contributing from the eastern and south-eastern portions of the Kathmandu Valley to the Bagmati River (Fig. 1). The total length of the Godavari Khola is about $19 \mathrm{~km}$. It originates from the top of the Phulchauki Dada at the elevation of $2520 \mathrm{~m}$ and meets the Hanumante Khola at the elevation of $1280 \mathrm{~m}$. The Godavari Khola is a fifth-order stream which has high relief towards the southern part (Tamrakar and Bajracharya, 2012). It consists of several contributaries: Narsin Khola, Bistachhap Khola,

\footnotetext{
*Corresponding author:

E-mail address: sworupkgeologist@gmail.com
}

Dhamilo Khola, Lubu Khola and the Charkhande Khola. The lower order streams flow across the metasedimentary rocks whereas the higher order streams flow on the fluvio-lacustrine deposits. Sediment size distribution, hydraulic parameters, planform analysis, environment of deposition are important to characterise the stream (Shrestha and Tamrakar, 2007a; Tamrakar et al., 2011). Based on classification and competence evaluation, behaviour and nature of the river can be traced out. It is known that sediments in the stream have their origin from different sources. Therefore, the proportion of components that each source contributes to the mix varies over time and space, as a result of erosion processes that are on-going in the basin of contribution. In addition, erosion and 
sedimentation exacerbate the instability of the stream channel (Shrestha and Tamrakar, 2007a; Shrestha and Tamrakar, 2007b; Maharjan and Tamrakar, 2010; Tamrakar et al., 2011; Tamrakar and Bajracharya, 2012; Tamrakar et al. 2014). The present study aims to establish fluvial morphology and stability status of the Godavari Khola.

\section{GEOLOGIC SETTING}

Many scientists have studied basin fill sediments of the Kathmandu Valley sediments from various points of views (Sharma and Singh, 1966; Yoshida and Igarashi, 1984; Dangol, 1985, 1987; Yoshida and Gautam, 1988; Shrestha et al. 1998; Sakai, 2001). The Kathmandu basin consists of thick succession of fluvial and lacustrine sediments of Plio-Pleistocene to Holocene epoch composed mainly of unconsolidated to semi- consolidated sand, gravel, peat, silt, clay and carbonaceous black clay locally known as 'Kalimati' lying unconformably on the Paleozoic rocks of the Phulchauki Group and partly of the Bhimphedi Group of the Kathmandu Complex, which forms the Mahabharat Range surrounding the Kathmandu Valley (Fig. 2). The thickness of the sediment in the valley basin is about 550 to $600 \mathrm{~m}$ (DMG, 1998) or more than $650 \mathrm{~m}$ (Moribayashi and Maruo, 1980; Maruo et al., 1999) in the central part.

The Kathmandu Basin lies on the Kathmandu Nappe which consists of metamorphic nappe and the overlying fossiliferous Tethyan sediments, both belonging to the Kathmandu Complex (Sakai, 2001). The northern slope of the Kathmandu Valley is composed of gneiss, schist and granite of the Shivapuri gneiss and the granite injection Complex whereas weakly metamorphosed rocks of the Phulchauki Group like marble, limestone,

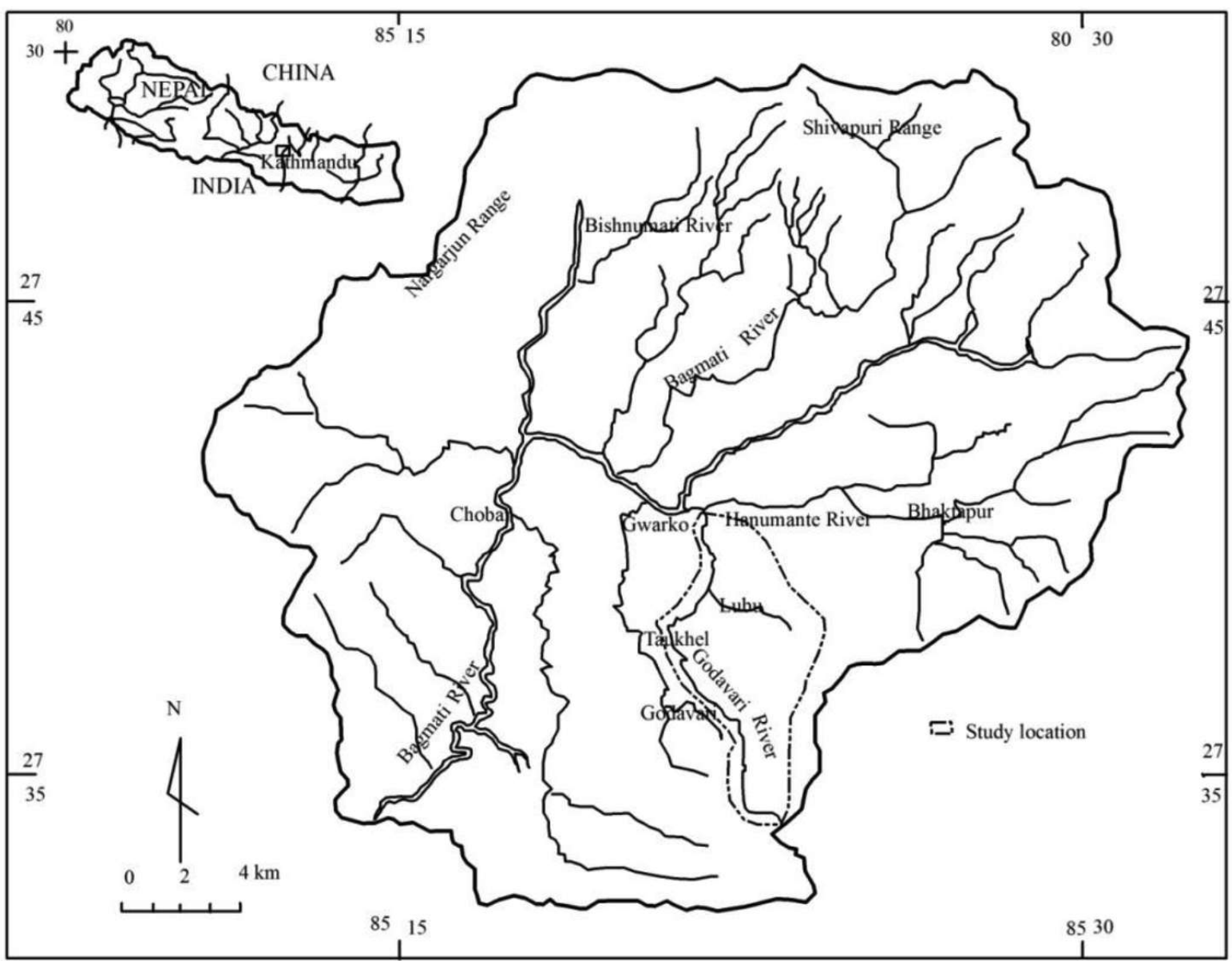

Fig. 1 Location map of the the Godavari watershed in the southeast part of the Kathmandu Valley 


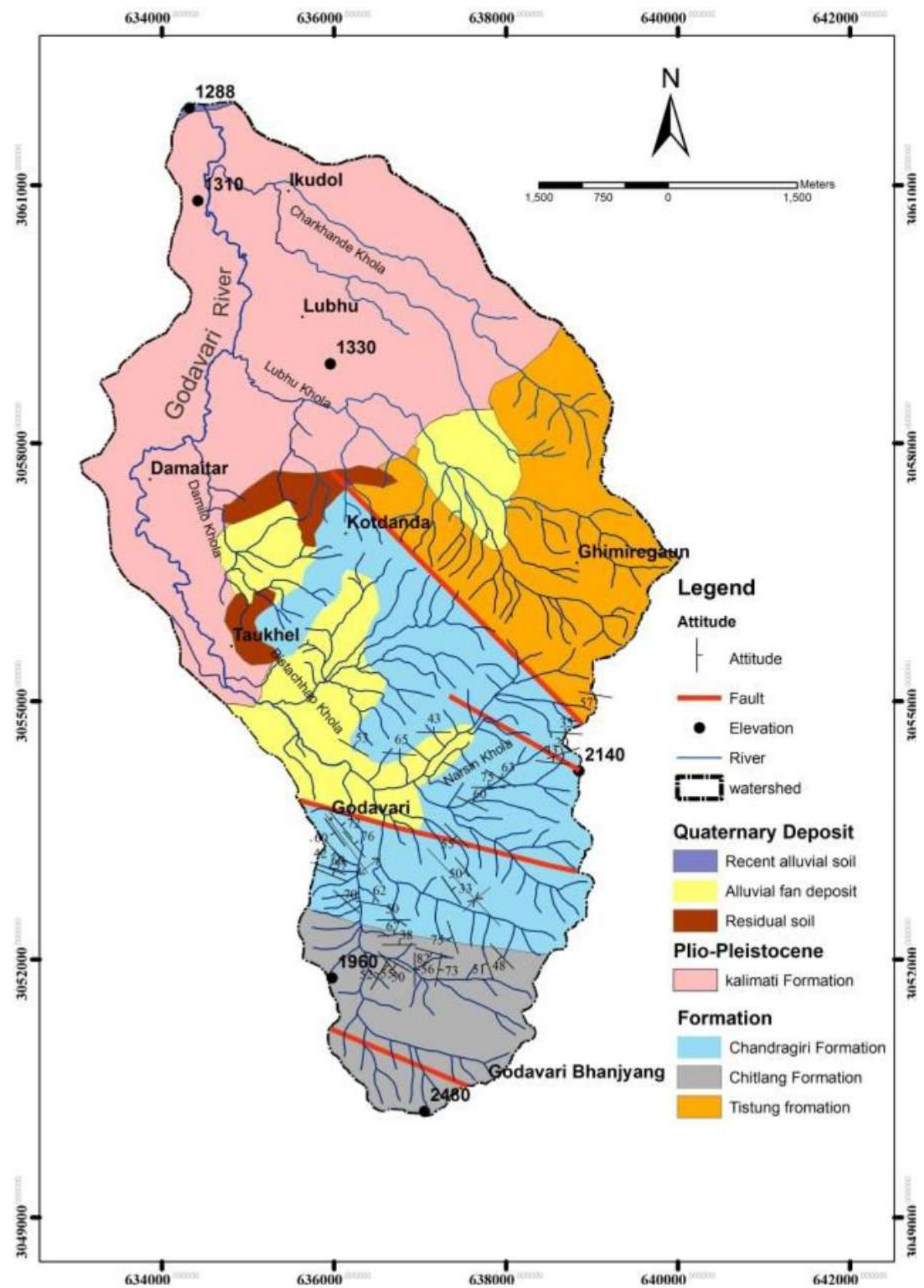

Fig. 2 Geological map of the Godavari Khola basin (Modified from Stöcklin,1980) 


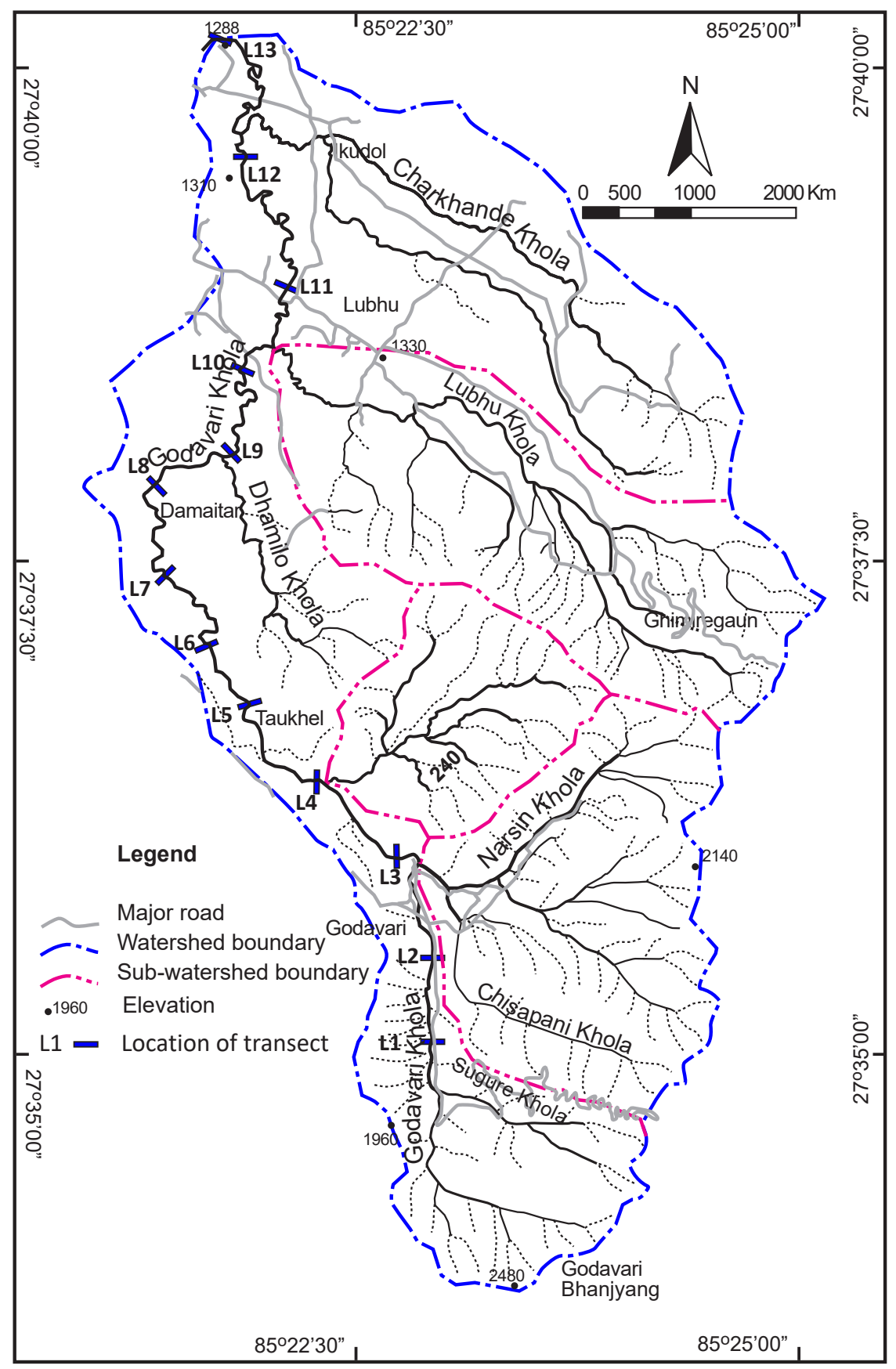

Fig. 3 Location of stream transects along the Godavari Khola

shale, phyllite, siltstone, quartzite are found in the eastern, western and the southern slopes of the Kathmandu Valley (DMG, 1998).

\section{METHODOLOGY}

Firstly, on topographic maps $(1: 25,000$ and $1: 10,000)$ stream planform patterns were measured and reconnaissance field visit was made along the stream. Secondly, thirteen representative transects of the Godavari Khola (Fig. 3) were selected based on their planform, nature of channel, and bank conditions. Then, these segments were surveyed for cross-sections and longitudinal profiles using an Ushikata Theodolite, staff and a measuring tape. The existing channel was surveyed for hydraulic parameters and evaluating its planform analysis. 


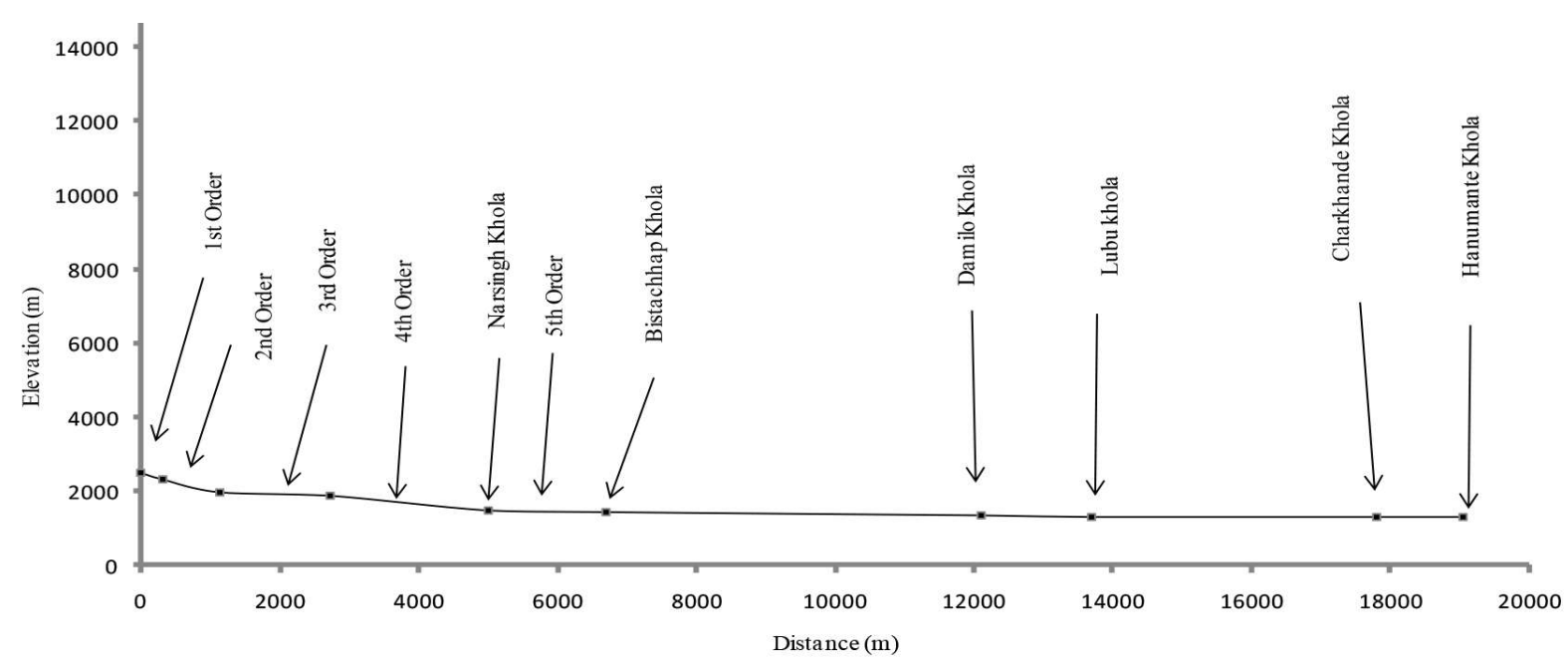

Fig. 4 Longitudinal profile of the Godavari Khola

Morphological data were derived using crosssectional analysis of the stream segments and measurement from the Topo map, 1:25000. The stream segments were classified after Rosgen (1994). In order to characterise grain size, Wolman's (1954) pebble counting method was applied. The median grain size obtained from reach-scale counting was applied in stream classification after Rosgen (1994), while the size distribution of the samples from the wetted perimeter of riffle cross-section was considered in evaluating shear stress. The bar surface samples were analysed for the grain size parameters. Hydraulic and geomorphologic analyses were made to obtain the sedimentology and dynamics of the Godavari Khola.

\section{RESULTS}

\section{Stream Order and Relief}

The drainage pattern of the Godavari River is dendritic and river is of 5th order stream (Figs. 4 and 5) which flows from the elevation of $2520 \mathrm{~m}$ and meets the Hanumante Khola at $1280 \mathrm{~m}$. In the Godavari watershed the relief is high in the southeast part and low in the northwest part, and ranges from extremely high $(>240)$ to extremely low $(0-15)$ that shows the more erosional activities occurring in the southeast part.

\section{Planforms}

Sinuosity (k) ranges from 1 to 1.30 (Table 1). It is high in the 11th transect, and indicates the high matureness, high meandering and low eroding potential. Sinuosity is low in $1 \mathrm{st}, 2 \mathrm{nd}, 4$ th, 8 th and 10th transect indicating immature drainage system and less meandering with high erosion potential.

High value of radius of curvature shows that the stream is less meander and low value shows that the river is highly meander. The radius of curvature is the highest in the 2nd transect and is the lowest in the 9th transect. Meander wavelength is high in 2nd transect and low in 7th transect (Table 1).

The width of the corridor is defined by the lateral extent of the river meanders, called the meander belt width which is governed by valley landforms, surficial geology, and the length and slope requirements of the river channel. The mean value of meander belt width is highest in 8th transect and lowest in 4th transect (Table $1)$.

\section{Stream Morpho-hydrologic Parameters}

In the investigated transects of the Godavari Khola, the channel width ranges from $3.2 \mathrm{~m}$ to $28 \mathrm{~m}$ (Table 2). The Godavari river channel depth varies from $0.30 \mathrm{~m}$ to $0.90 \mathrm{~m}$ where the lowest channel depth is of $3 \mathrm{rd}$ transect and highest is of 13th transect. The maximum depth at bankfull ranges from $0.6 \mathrm{~m}$ to $1.2 \mathrm{~m}$. The width/depth ratio ranges from 7.4 to 62.29 , which is lowest in 1st transect and highest in 9th transect showing the vulnerability for the near bank erosion. The floodprone width ranges from $7.5 \mathrm{~m}$ to $122.6 \mathrm{~m}$ which is lowest in 7th and highest in 13th transect because of 


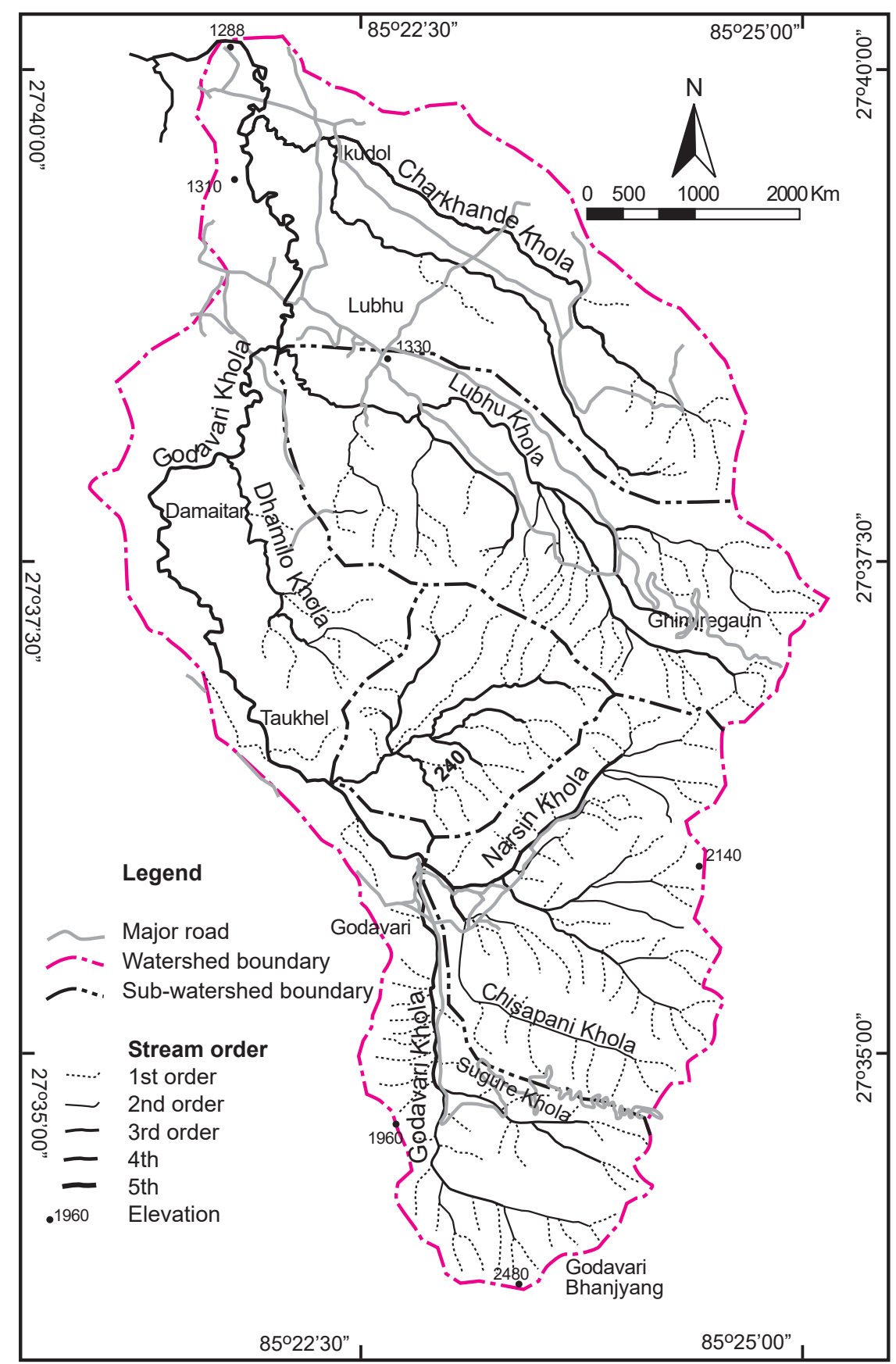

Fig. 5 Map showing stream order of the Godavari Khola

the flat topography and high bankfull discharge. The bankfull cross-sectional area varies from 1.4 to $18.5 \mathrm{~m}^{2}$, which is lowest in 1st transect and highest in 13th transect. The width of flood plain varies from $3.2 \mathrm{~m}$ to $122.60 \mathrm{~m}$. Entrenchment ratio varies from 1 to 4.37 and shows high affinities of flooding in 7th transect and low affinity of flooding in 13th transect.

\section{Stream Water Surface Slope}

Slope of the Godavari Khola is concave upward in shape. The stream water surface slope varies from 0.03 $\mathrm{m} / \mathrm{m}$ to $0.12 \mathrm{~m} / \mathrm{m}$ which is low in 8 th, 11 th, and 13 th transects whereas highest in 1 st transect. Stream with steep slope has low sinuosity whereas stream with gentle slope is found to have high sinuosity. 





Table 2: Hydraulic data of the Godavari Khola

\begin{tabular}{lccccccccccccc}
\hline \multicolumn{1}{c}{ Transect } & 1 & 2 & 3 & 4 & 5 & 6 & 7 & 8 & 9 & 10 & 11 & 12 & 13 \\
\hline Channel Slope, S (m/m) & 0.12 & 0.07 & 0.05 & 0.06 & 0.11 & 0.05 & 0.06 & 0.03 & 0.05 & 0.04 & 0.03 & 0.08 & 0.03 \\
Hydraulic radius, R (m) & 0.01 & 0.01 & 0.01 & 0.04 & 0.03 & 0.03 & 0.02 & 0.02 & 0 & 0.02 & 0.02 & 0.04 & 0.02 \\
Crosssectional area at bankfull stage, $\mathrm{A}\left(\mathrm{m}^{2}\right)$ & 1.4 & 2.9 & 3.4 & 4.3 & 3.2 & 8.8 & 4.3 & 6.0 & 7.6 & 5.8 & 10.0 & 6.7 & 18.5 \\
Manning roughness cofficient, $\mathrm{n}$ & 0.44 & 0.44 & 0.5 & 0.35 & 0.41 & 0.39 & 0.36 & 0.32 & 0.42 & 0.43 & 0.38 & 0.4 & 0.4 \\
Bankfull Discharge, Q= (A.R $\left.\mathrm{R}^{\wedge} / 3 . \mathrm{S}^{\wedge 1 / 2}\right) / \mathrm{n}\left(\mathrm{m}^{3 / \mathrm{s}}\right)$ & 0.01 & 0.03 & 0.02 & 0.06 & 0.06 & 0.1 & 0.05 & 0.04 & 0.02 & 0.06 & 0.07 & 0.1 & 0.11 \\
Velocity, $\mathrm{V}=\mathrm{Q} / \mathrm{A}(\mathrm{m} / \mathrm{s})$ & 0.39 & 0.33 & 0.20 & 0.42 & 0.50 & 0.40 & 0.44 & 0.33 & 0.25 & 0.26 & 0.40 & 0.28 & 0.24 \\
\hline
\end{tabular}

\section{Stream Classification}

Sinuosity, entrenchment ratio, W/D ratio, slope and bed material were considered in classifying stream types (Table 3).

\section{'B3'stream}

Stream at transect 2 nd is riffle dominant channel with stable profile and banks with W/D ratio greater than 12. The sinuosity is high with gentle sloping valleys and constitutes riffle dominated channel. The bed material is composed of cobble.

\section{'B4'stream}

Streams at transect 1st, 5th and 6th are moderately entrenched with moderate W/D ratio. Slopes at 1st and 5th transect is larger than that of the 6th transect. Bed material consists of gravel in all the transects that constitute few point bars as the channel elements.

\section{'C4'stream}

Streams at transect 7th, 9th, 10th and 13th are moderately entrenched with W/D ratio greater than 12 . The sinuosity is high with very gentle slopes, and constitutes numerous point bars deposit. The bed material is composed of fine gravel to very coarse gravel. The banks frequently exhibit erosion scars.

\section{'C5'stream}

Stream at transect 8 th is moderately entrenched with W/D ratio greater than 12 . The sinuosity is moderate with gentle slopes

\section{'F4'stream}

Streams at transect 3th, 4th and 12th are less entrenched with high W/D and somewhat low sinuosity $(>1.2)$. Its bed material is of pebble size grade.

\section{'E4'stream}

Stream at 11th transect is of low gradient, meandering riffle/pool, high entrenched with low W/D ratio and high sinuosity $(>1.5)$. The channel is very efficient and stable. Its bed material is of gravel.

\section{Depositional environment}

The vertical distribution within measured sections of the study area shows two significant depositional

Table 3: Summary of Rosgen stream classification (level I and II) of the Godavari Khola

\begin{tabular}{|c|c|c|c|c|c|c|c|c|c|c|c|c|c|}
\hline Transect & 1 & 2 & 3 & 4 & 5 & 6 & 7 & 8 & 9 & 10 & 11 & 12 & 13 \\
\hline Width at bankfull, $\mathrm{W}_{\mathrm{bkf}}(\mathrm{m})$ & 3.2 & 6.1 & 11.4 & 8.0 & 6.3 & 14.3 & 7.5 & 11.4 & 21.8 & 13.2 & 11.2 & 18.5 & 28.0 \\
\hline Max. depth bankfull, $\mathrm{D}_{\max }(\mathrm{m})$ & 0.6 & 0.7 & 0.7 & 0.8 & 0.9 & 1.1 & 1.1 & 1.2 & 1.0 & 0.7 & 1.2 & 0.7 & 1.0 \\
\hline Width flood prone area, $\mathrm{W}_{\mathrm{fpa}}(\mathrm{m})$ & 10.6 & 10.3 & 13.5 & 9.7 & 12.9 & 31.3 & 57.0 & 35.0 & 62.5 & 112.1 & 100.2 & 56.1 & 122.6 \\
\hline Width-depth ratio & 17.7 & 12.7 & 38.0 & 14.8 & 12.4 & 22.3 & 13.2 & 21.6 & 62.6 & 30.1 & 12.5 & 51.4 & 42.4 \\
\hline Entrenchment ratio, $E R=W_{\text {fpa }} / W_{\text {bkf }}$ & 3.31 & 1.69 & 1.2 & 1.2 & 2.1 & 2.2 & 7.6 & 3.1 & 2.9 & 8.5 & 8.9 & 3.0 & 4.4 \\
\hline Sinuosity, K & 1.04 & 1.06 & 1.34 & 1.16 & 1.35 & 1.33 & 1.45 & 1.15 & 1.4 & 1.18 & 1.57 & 1.24 & 1.26 \\
\hline Slope $(\mathrm{m} / \mathrm{m})$ & 0.12 & 0.07 & 0.05 & 0.06 & 0.11 & 0.05 & 0.06 & 0.03 & 0.05 & 0.04 & 0.03 & 0.08 & 0.03 \\
\hline Dominant channel material, $\mathrm{D}_{50} \quad(\mathrm{~mm})$ & 40 & 85 & 28 & 26 & 28 & 25 & 40 & 0.65 & 30 & 9 & 20 & 28 & 35 \\
\hline Rosgen stream type & B4a & B3a & $\mathrm{F} 4 \mathrm{~b}$ & B4a & B4a & $\mathrm{C} 4 \mathrm{~b}$ & $\mathrm{C} 5 \mathrm{~b}$ & $\mathrm{C} 4 \mathrm{~b}$ & $\mathrm{C} 4 \mathrm{~b}$ & $\mathrm{C} 4 \mathrm{~b}$ & $\mathrm{E} 4 \mathrm{~b}$ & $\mathrm{~F} 4 \mathrm{~b}$ & $\mathrm{C} 4 \mathrm{~b}$ \\
\hline
\end{tabular}


elements used to reconstruct the Godavari basin based on clast assemblages, textural associations, colour and relative distribution/geometry, which were all derived locally from the Phulchauki ridge to the southwest. These elements constitute the significant sediment contributors that filled the Godavari basin.

The two depositional elements include: a) Stream flood deposit and b) Alluvial fan deposit. Stream flood deposit consists of 3 facies formed due to clastsupported debris flow deposit, matrix-supported debris flow deposit, and matrix-supported stream flood deposit seen on 2nd, 3rd, 6th, 7th, 8th, 9th, 12th and 13th transects (Fig. 6 ). Lake sediments are overlain by the debris flow deposit in most transect which resembles fanning of streams over the paleolake (Bull, 1977; Heward, 1978; Rust and Koster,1984; Boggs, 1987).

Stream flowing from steeper slopes within the region having abundant loose sediment, soil and weathered rock initiates the debris flow. It contains the gravel of different size and shape with higher percentage of sand, silt and clay (Fig. 7). In the Godavari River basin, the Kalimati Formation is overlain by the debris flow deposit of the Godavari Khola (Fig. 6). In the debris flow deposit, gravels are haphazard oriented, poorly sorted and mixed with sand, silt and clay. As the river flow a long distance, the sediment becomes finer. The lacustrine sediments are overlain by the river sediment in most of the part of the Kathmandu Basin.

\section{Depositional and Erosional Processes}

Here, the deposits are mainly seen on bar due to decrease in slope and increase in cross sectional area which is seen in lower transects, whereas in the upper (upstream) transect the deposition are due to increase in boundary resistance, flow separation and obstruction to flow. Block quarrying, abrasion, corrosion, and mass failure are the erosional processes in 1st, 2nd and 6th transects whereas pre-weakening process, fluvial processes, mass failure are the main reasons for the erosional processes of 3rd, 4th, 5th, 7th, 8th, 9th, 10th, 11th, 12th and 13th transects.

\section{Stream Sediment Dynamics}

Particle size distribution curves of riffle indicates that the dominant grain size deposited by the Godavari
Khola in riffle range from very fine to very coarse gravel and silt/clay, and in bar grain size is mainly sand. Stream bed material varies in size due to the stream dynamics of the river and the morphometric parameters.

River is a dynamic system governed by hydraulic and sediment transport process responsible for changing conditions in its environment by modifying its crosssectional shape, thus increasing or decreasing its local sediment carrying capacity, observed as patterns of erosion and deposition.

Hydraulic radius, which is the ratio of area of crosssection of transect to a wetted perimeter, is the highest in 11th transect, and is least in 3rd transect. The value of Manning's roughness coefficient depends on the different factors such as degree of irregularity, variation in channel cross-section, effect of obstruction, amount of vegetation and degree of meandering (modified from Aldridge and Garrett, 1973). In an undisturbed channel, it increases from downstream to upstream. The calculated $\mathrm{n}$ value was used for calculating the bankfull discharge.

The bankfull velocity was calculated using the continuity equation. It is found maximum $(1 \mathrm{~m} / \mathrm{s})$ at 5 th transect. Bank-full discharge was estimated by using Manning's equation (Chow, 1959).

$$
\mathrm{Q}=\left(\mathrm{A} \cdot \mathrm{R}^{2 / 3} \cdot \mathrm{S}^{1 / 2}\right) / \mathrm{n}
$$

where, $\mathrm{A}=$ cross-sectional area at bankfull stage, $\mathrm{Q}$ = bankfull discharge, $\mathrm{S}=$ average channel slope, $\mathrm{n}=$ Manning's roughness coefficient, $\mathrm{R}=$ hydraulic radius

Discharge increases from upstream to downstream due to decrease in roughness and contribution of its tributaries at downstream. The bankfull discharge is highest in 13th transect $\left(4.37 \mathrm{~m}^{3} / \mathrm{s}\right)$ and lowest in 1st transect $\left(0.54 \mathrm{~m}^{3} / \mathrm{s}\right)$. A positive relation is seen between stream cross-sectional area and bankfull width, depth and discharge (Fig. 8).

\section{Stream Competence Evaluation}

For coarse sediment moving on the bed of a channel, boundary shear stress may be a better measure of competence than the average water velocity (Baker and Ritter, 1975). The boundary shear on bed due to the channel is calculated (Table 4) using the following relation: 

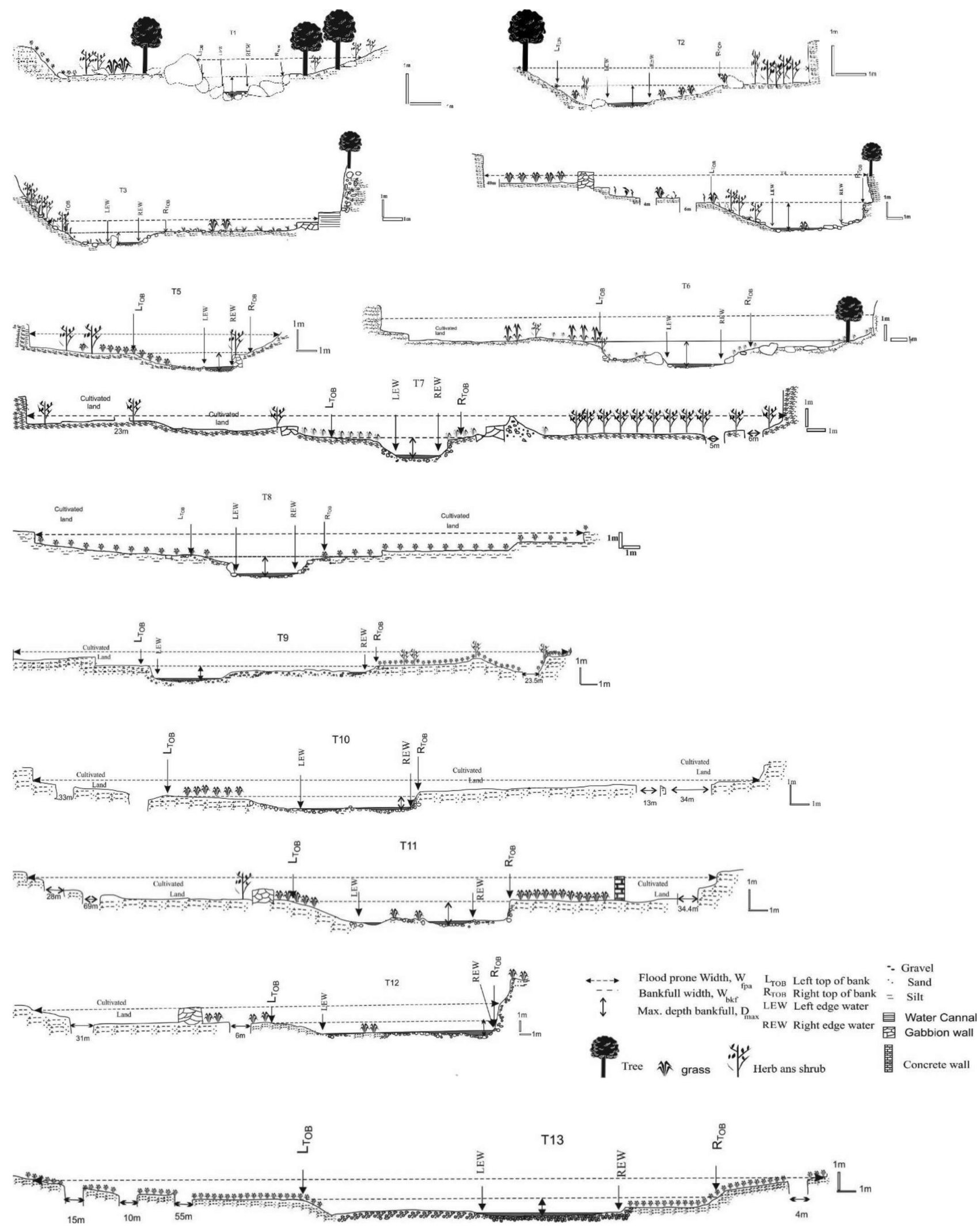

Fig. 6 Cross-sections of transects in the Godavari Khola 

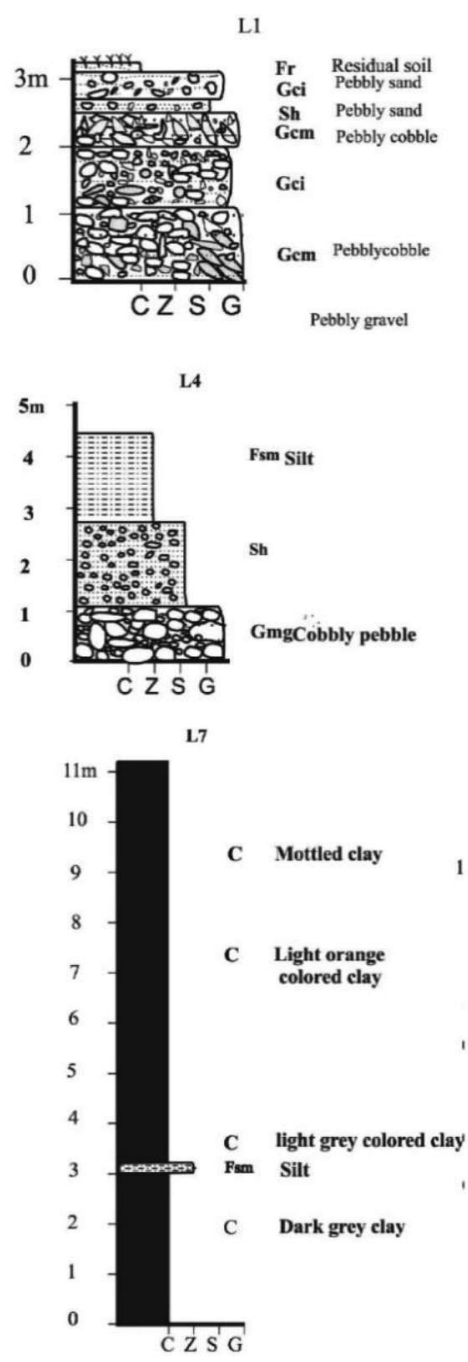

L10

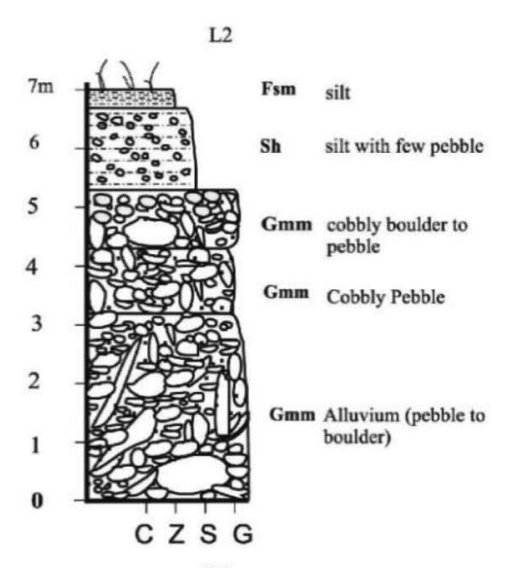

L5

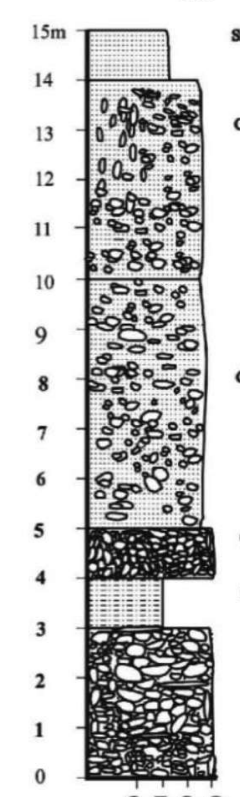

C Z S G
$\mathbf{L 3}$

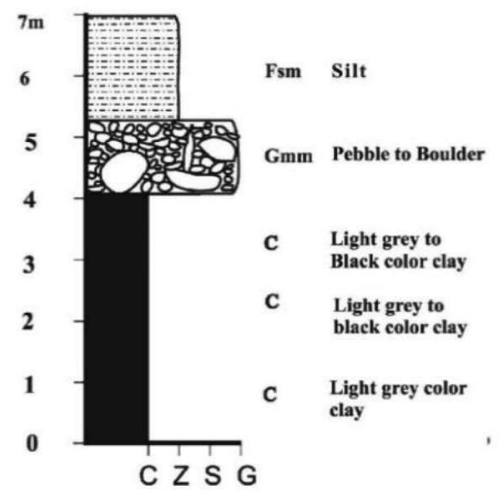

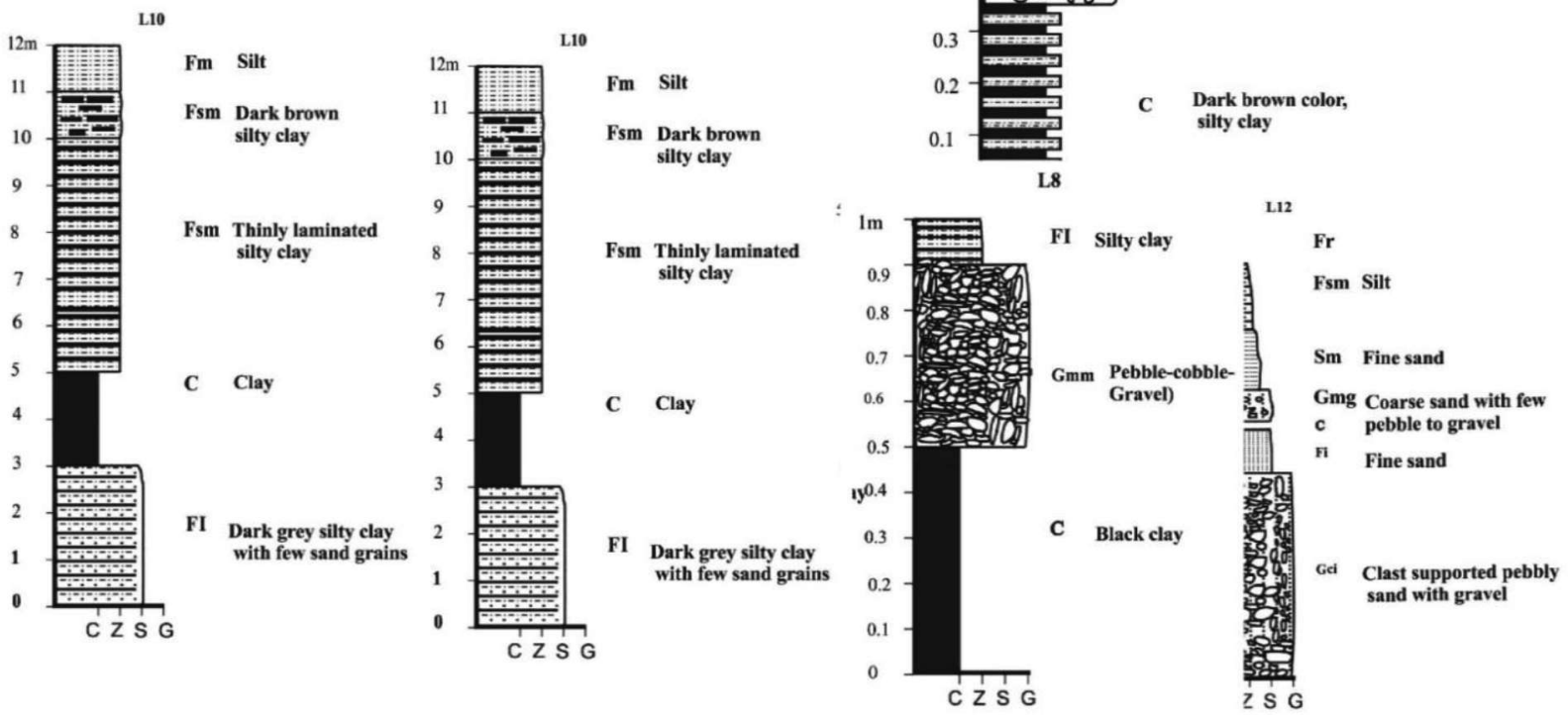

Fig. 7 Graphic logs of fluvio-lacustrine sediments. Location numbers are shown in Fig. 2b. 


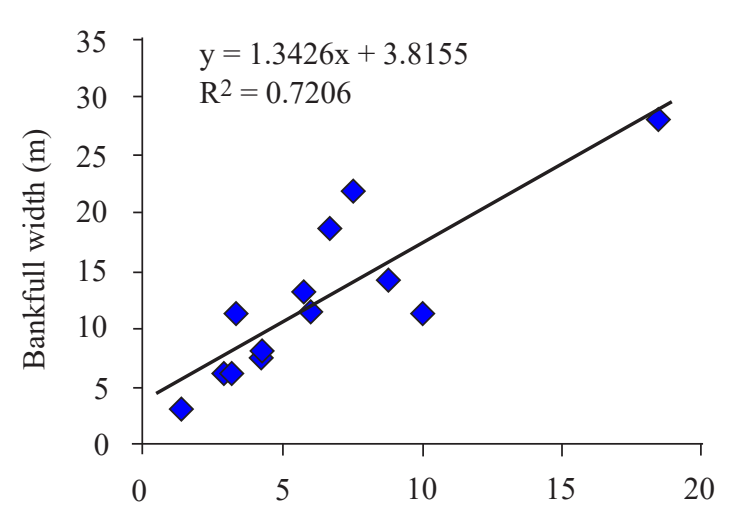

(a)

Stream cross-sectional area $\left(\mathrm{m}^{2}\right)$

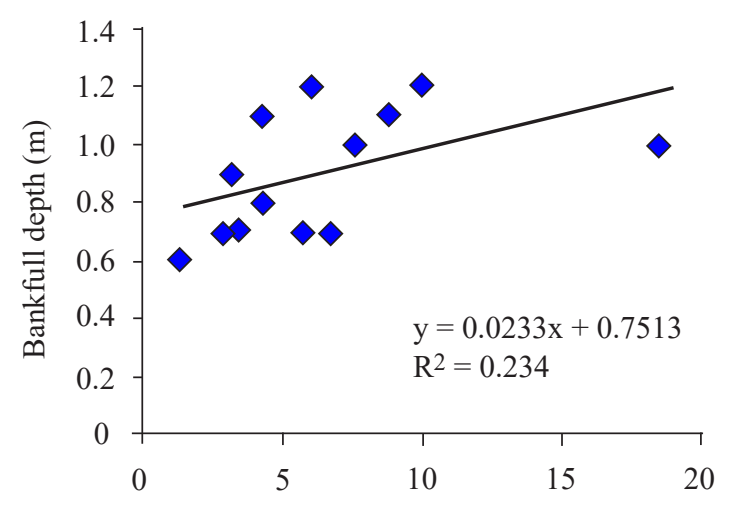

(b)

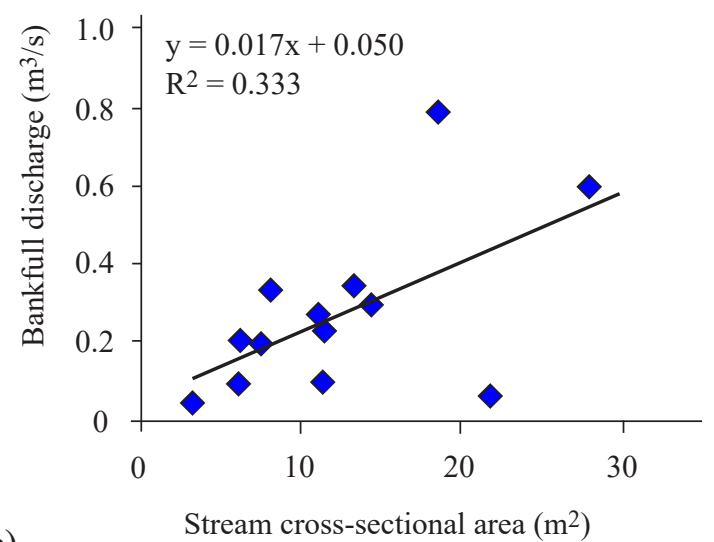

(c)

Fig. 8 Relationships among stream cross-sectional area and (a) bankfull width, (b) bankfull depth, and (c) bankfull discharges

$$
\tau=\gamma \mathrm{RS}
$$

Where, $\tau=$ boundary shear stress, $\gamma=$ specific weight of water, $\mathrm{R}=$ hydraulic radius, and $\mathrm{S}=$ slope.

Sediment transport in gravel stream is usually analysed by estimating the critical shear stress to move particular sized particle. It is a measure of the force required to mobilize and transport particle resting on stream bed, calculated using bar and riffle samples (Andrew, 1983):

$$
\tau_{\text {cr }}=0.0834\left(\operatorname{Rd}_{50} / \mathrm{Bd}_{50}\right)^{-0.87}
$$

Where, $\tau_{\mathrm{cr}}=$ critical shear stress, $\operatorname{Rd}_{50}=$ mean diameter of riffle sample, and $B d_{50}=$ mean diameter of bar sample

In the Godavari Khola, the sediment transported in riffle is coarse sand in 8th transect, cobble in 2nd transect, and very fine to very coarse gravel in the remaining transects. In the bar, the sediment analysed shows the dominance of silt/clay which is in 1th, 4th, 5th, 6th, 7th, 8th, 9th, 10th transect, fine sand in 11th, medium sand in 3th and 12th transect gravel in 2nd and very coarse gravel in 13th transect.

Stream power per unit downstream length, $\Omega=$ $\rho g Q S$, where $\rho=$ density of water $\left(1000 \mathrm{~kg} / \mathrm{m}^{3}\right), g=$ acceleration due to gravity $\left(9.8 \mathrm{~m} / \mathrm{s}^{2}\right), \mathrm{Q}=$ discharge $\left(\mathrm{m}^{3} / \mathrm{s}\right)$, and $\mathrm{S}=$ channel slope $(\mathrm{m} / \mathrm{m})$, is the capacity of stream to carry sediments. This varies from 21.54 to $168.53 \mathrm{KN} / \mathrm{s} / \mathrm{m}$ (Table 4).

\section{Aggrading/Degrading Potential}

Aggradation/degradation potential of the Godavari Khola was evaluated using Schumm's (1963) relationship:

$$
\begin{aligned}
& \mathrm{W}_{\mathrm{bkf}} / \mathrm{D}_{\mathrm{bkf}} \\
& \left.\left.2 \mathrm{D}_{\mathrm{bkf}}\right)\right\}^{-1.08}
\end{aligned}
$$

Where, Sc is silt and clay percentage in wetted perimeter of a riffle cross-section and $\mathrm{Sb}$ is silt and clay percentage of bar material. The transects $3 \mathrm{rd}$, 4th, 5th, 6th, 7th, 8th, 9th, 10th and 12th plot on the aggrading field (Fig. 9), but transect 1st, 2nd, 11th, and 13th plot on the degrading field.

\section{DISCUSSIONS}

Fluvial dynamics affect various factors such as planform, stream morpho-hydrologic parameters, and depositional environment. It has been observed that potential disturbing factors of the Godavari Khola are sediment excavation, human encroachment of the streambank, vegetation clearing, channelization, 
Fluvial morphology and dynamics of the Godavari Khola, southeast Kathmandu, Central Nepal

Table 4: Competence, sediment transport and stream power of the Godavari Khola

\begin{tabular}{|c|c|c|c|c|c|c|c|c|c|c|c|c|c|}
\hline Transect & 1 & 2 & 3 & 4 & 5 & 6 & 7 & 8 & 9 & 10 & 11 & 12 & 13 \\
\hline Stream slope, $\mathrm{S}(\mathrm{m} / \mathrm{m})$ & 0.12 & 0.66 & 0.52 & 0.0588 & 0.124 & 0.0523 & 0.064 & 0.03 & 0.0465 & 0.041 & 0.033 & 0.05 & 0.017 \\
\hline Bankfull Discharge, Q (m3/s) & 0.01 & 0.03 & 0.02 & 0.061 & 0.059 & 0.096 & 0.045 & 0.036 & 0.019 & 0.059 & 0.073 & 0.102 & 0.114 \\
\hline Boundary shear stress, $\tau\left(\mathrm{KN} / \mathrm{m}^{2}\right)$ & 1.18 & 0.92 & 0.4 & 2.154 & 3.313 & 1.256 & 1.313 & 0.542 & 0.132 & 0.973 & 0.623 & 2.029 & 0.405 \\
\hline Critical shear stress, $\quad \tau_{\text {cr }}\left(\mathrm{KN} / \mathrm{m}^{2}\right)$ & 0.003 & 0.027 & 0.001 & 0.0001 & 0.003 & 0.0002 & 0.0002 & 0.003 & 0.0002 & 0.009 & 0.001 & 0.001 & 0.094 \\
\hline Sediment transport, $\mathrm{Q}_{\mathrm{b}}$ (tonnes/day) & 426 & 34.3 & 288 & 14490 & 1125 & 6856.6 & 8238.2 & 172.5 & 642.7 & 107.7 & 527.6 & 1476 & 4.3 \\
\hline Stream power $(\Omega)=\gamma \mathrm{QS}(\mathrm{KN} / \mathrm{s} / \mathrm{m})$ & 0.02 & 0.17 & 0.1 & 0.0352 & 0.072 & 0.0492 & 0.0282 & 0.01 & 0.0087 & 0.024 & 0.023 & 0.05 & 0.019 \\
\hline
\end{tabular}

damping, discharge of domestic and industrial effluents and garbage dumping. In Godavari Khola, sinuosity increases towards downstream. The high value of width/depth ratio in the 9th transect shows that it is prone to near bank erosion, high value of entrenchment ratio in the 13th transect shows high affinity of flooding. In upstream transects the bankfull discharge is low as the manning's roughness value is high suggesting relatively high obstruction and high vegetation present in the upstream segments.

Due to the low hydraulic radius and high meander, point bars of boulder to cobble are present in the upstream transects. Comparatively, the downstream transects have higher floodplain area due to relatively weak bank materials, high sinuosity, flat terrain and high velocity of river water leading the bar deposit and over bank deposits. Meander belt width, meander length, and radius of curvature show high magnitude of

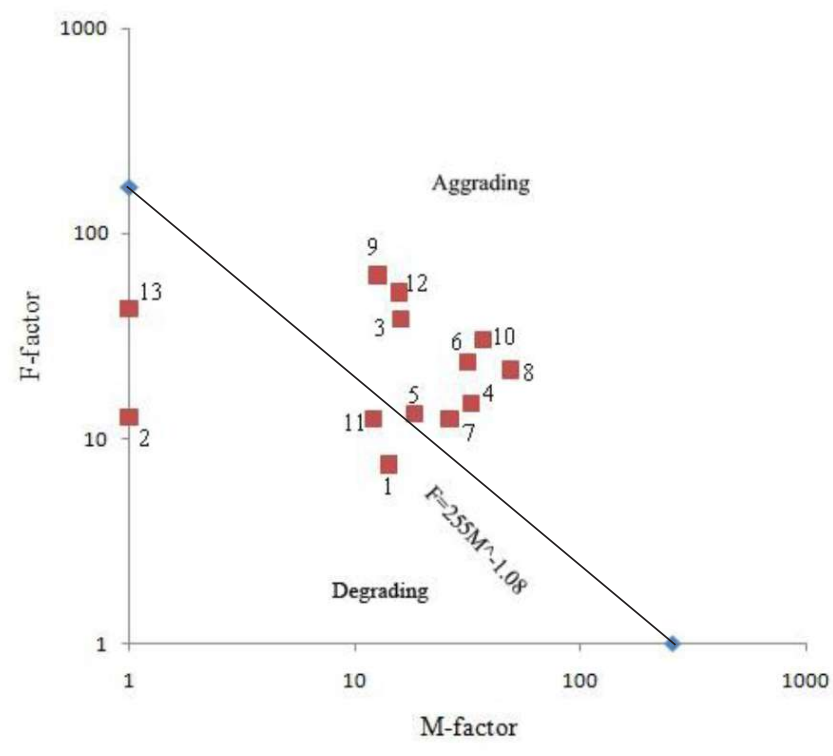

Fig. 9 Stability status of the Godavari Khola planform changes. Stream power is greater in second and third transects than the downstream transects and is influenced by the slope.

Based on geomorphic analysis, degrading stream segments are found in the 1st and the 2nd whereas in the lower transects, E4-and C4-stream types are degrading due to high bankfull depths,

\section{CONCLUSIONS}

The Godavari Khola flows over the fluvio-lacustrine sediments, exhibiting a bedrock-alluvial transition of the valley which is straight in upstream and becomes sinuous toward downstream. The Godavari Khola is classified into C4-, C5-, B3-, B4-, E4- and F4-type streams. Positive relations between watershed area and stream cross-sectional area of flow, bankfull width and discharge with respect to distance were observed.

The depositional elements of the Godavari River include: a) Stream flow deposit: channel deposit, point bar deposit, mid channel bars, floodplain deposit, and b) Debris flow deposit.

The Godavari Khola in the southern part contains higher energy for bed load transport, whereas in the northern part shows lower efficiency with the decrease of slope and competence.

The stability status of the Godavari Khola suggests that the stream segments 1, 2,11 and 13 are degrading and the remaining nine segments are aggrading. Because of the huge width/depth ratio in majority of the downstream channels, bank erosion is comparatively prone in the downstream segments of the Godavari Khola. Bed incision is however prone in segments 11 and 13. 


\section{ACKNOWLEDGEMENT}

Authors are thankful to Central Department of Geology for providing facilities for conducting present research work.

\section{REFERENCES}

Aldridge, B.N., and Garrett, J.M., 1973. Roughness coefficients for stream channels in Arizona: U.S. Geological Survey Open-File Report, 87 p.

Andrew, E.D., 1983. Entrainment of Gravel from Naturally Sorted Riverbed Material Geological Society of American Bulletin, v. 94, pp. 1225-1231.

Baker, V.R. and Ritter, D.F., 1975. Competence of rivers to transport coarse bedload material: Geol. Society of America Bull., v. 86, pp. 975-978.

Boggs, S. Jr., 1987. Principles of Sedimentology and Stratigraphy. Merrill, Columbus., pp. 784.

Bull, W.B., 1977. The alluvial fan environment. Progress in Physical Geography, v. 1, pp. 222-270.

Chow, V.T., 1959. Open channel hydraulic. McGraw-Hill. Inc., New York.

Dangol, G.M.S., 1985. Geology of the Kathmandu fluvial lacustarine sediments in the light of new vertebrate fossils occurrences. Jour. Nepal Geol. Soc., v.3, pp.43-57.

DMG/ BGR/DOI, 1998. Hydrogeological Conditions and Potential Barrier Sediments in the KathmanudValley.Technical Cooperation ProjectEnvironmental Geology. Final report pp.17-59.

Heward, A.P., 1978. Alluvial fan sequence and mega sequence models: with examples from Westphalian DStephanian B coalfields, Northern Spain. In: Miall, A. D., ed., Fluvila Sedimentology, Canadian Society of Petroleum Geologist. Memoir 5, pp. 669-702.

Maharjan, B. and Tamrakar, N.K., 2010. Morphohydraulic parameters and existing stability conditions of the Nakhu River, southern Kathmandu, central Nepal. Bull. Dept. Geol., v. 13, pp. 1-12.

Maruo, Y., Moribayashi, S. and Tandukar, R.P., 1999. Gravity map of Kathmandu Valley. Institute for International Cooperation, JICA, Tokyo, 11 p.

Moribayashi, S., and Maruo, Y., 1980. Basement topography of the Kathmandu Valley, Nepal- An application of gravitational method to the survey of a tectonic basin in the Himalayas Jour. Japan Soc. Eng. Geol. v. 21(2), pp. 80-87.

Rosgen, D.I., 1994. A classification of natural rivers, Cantena, v. 22, pp. 169-199.

Rust, B.R. and Koster, E.H., 1984. Coarse alluvial deposits.
In: Walker, R. G., ed., Facies Models, 2nd ed. Geoscience Canada. Reprint Series I, pp. 53-69.

Sakai, H., 2001. Stratigraphic division and sedimentary facies of the Kathmandu Basin Group, central Nepal. Jour. Nepal Geol. Soc., Special Issue, v. 25, pp. 19-32.

Schumm, S.A., 1963, A tentative classification system of alluvial rivers. Circular 477, U.S Geological survey, Washington, D.C.

Sharma, P.N. and Singh, O.R., 1966. Groundwater Resources of Kathmandu Valley, Supplementary Report, Geol. Soc. India.

Shrestha, P. and Tamrakar, N.K., 2007a. Bank erosion process and bank material loss potential in Manahara River, Kathmandu, Nepal. Bulletin of the Department of Geology, Tribhuvan University, Kathmandu, Nepal., v. 10, pp. 35-44.

Shrestha, P. and Tamrakar, N.K., 2007b. Streambank erodibility and lateral instability hazard in the Manahara River, Kathmandu basin, Nepal. Jour. Nepal Geol. Soc., v. 35, pp. 55-65.

Shrestha, P. and Tamrakar, N.K., 2012. Morphology and classification of the main stem Bagmati River, Central Nepal. Bull. Dept. Geol., Tribhuvan University, v. 15, pp. 23-34.

Stöcklin, J. and Bhattarai, K.D., 1977. Geology of the Kathmandu area and Central Mahabharat range, Nepal Himalaya. Report of Department of Mines and Geology/ UNDP (unpublished report), 86p.

Tamrakar, N.K. and Bajracharya, R., 2012. Basinal and planform characteristics of the Kodku and the Godavari Rivers, Kathmandu, Central Nepal. Bull. Dept. Geol., Tribhuvan University, v. 15, pp. 15-22.

Tamrakar, N.K., Bajracharya, R. and Shrestha, P., 2011. River dynamics and existing stability condition of the Manahara River, Kathmandu basin, Central Nepal Himalaya. Bull. Dept. Geol., v. 14, pp. 1-8.

Tamrakar, N.K., Bajracharya, R., Sapkota, S., Thapa, I., Paudel, P. and Tamang, N.B., 2014. Riverbank erosion potential and channel stability status of the Kodku River, southern Kathmandu Basin, Central Nepal. Bull. Dept. Geol., v. 17, pp. 1-41.

Wolman, M.G., 1954. A method of sampling coarse riverbed materials. Trans. Am. Geophys, Union, v. 35, pp. 951-956.

Yoshida, M. and Igrashi, Y., 1984. Neogene to Quaternary lacustarine sediments in the Kathmandu valley, Nepal. Jour. Nepal Geol. Soc., Sp. Issue, v. 4, pp. 73-100.

Yoshida, M. and Gautam, P., 1988. Magnetostratigraphy of Plio-Pleistocene lacustrine deposits in the Kathmandu Valley, central Nepal. Proceeding of Indian National Science Academy, v. 54(3), pp. 410-417. 